УДК 339.13

Баула О.В., к.е.н., доцент Baula O. Candidate of Economic Sciences, Associate Professor Луцький національний технічний університет https://orcid.org/0000-0003-2609-0211 Саржан Ю.О., студентка

Sarzhan Y. Student

Луцький національний технічний університет https://orcid.org/0000-0003-2421-3249

\title{
ОСОБЛИВОСТІ СТРУКТУРНО-ФУНКЦІОНАЛЬНОЇ ОРГАНІЗАЦЇ̈ СВІТОВОГО ТА НАЦІОНАЛЬНИХ РИНКІВ ІНДУСТРІЇ МЕДІА ТА ЕНТЕРТЕЙМЕНТУ В СУЧАСНИХ УМОВАХ
}

\author{
Луцький національний технічний університет
}

В сучасному світі поняття медіа та ентертейменту є широковідомими та часто вживаними термінами. Найчастіше, зсилаючись на них, ми апелюємо до виробництва музики, ТБ або кінематографу. Проте над фактичним змістом цих понять пересічний споживач не замислюється. В контексті ринкового виробництва, поняття ентертейменту, як людської діяльності, поєднують з медіа індустрією, утворюючи комплексну індустрію медіа та ентертейменту (IME), яка є явищем, що постійно зростає та розвивається.

Перспективність IME, як галузі національного виробництва з високим інноваційним, інвестиційним та споживчим потенціалом, «притягує погляди» не лише власників великих світових компаній, але і урядів.

Природні особливості галузі обумовлені високим ступенем інтегрованості понять «медіа» та «ентертейменту», які виступають водночас взаємними доповненнями та елементами одне одного. Критичним аспектом, що відрізняє сучасну IME, як індустрію, від їі історичних попередників, є критерій комерційної спрямованості.

У статті досліджено особливості формування та трактування внутрішньої структури індустрії медіа та ентертейменту (IME). Проаналізовано особливості послуг IME, як продукту, що реалізується спеціалізованому ринку. Досліджено передумови кластеризації IME в межах національного ринку, зокрема виділено об'єктивні та іманентні для даної галузи виробництва фактори. А також проаналізовано приклад кластеризованого національного ринку IME, виділено слабкі та сильні сторони подібної форми організації даної галузі.

У статті обгрунтовано доцільність кластерної організації виробництва послуг IME в межах національного ринку, а також запропоновано комплексне трактування дефініції «індустрії медіа та ентертейменту», зважаючи на особливості поведінки споживача та організації виробничого процесу в умовах даного ринку.

Ключові слова: медіа, ентертеймент, індустрія медіа та ентертейменту, світовий ринок послуг, виробничий кластер.

\section{UNIQUE FEATURES OF THE STRUCTURAL AND FUNCTIONAL ORGANIZATION OF THE WORLD AND NATIONAL MARKETS OF THE MEDIA AND ENTERTAINMENT INDUSTRY IN MODERN CIRCUMSTANCES}

\author{
Lutsk National Technical University
}

In modern world, the concepts of media and entertainment are well-known and frequently used terms. Most frequently when referring to them we appeal to music, TV or cinema prpducrion. However, the average consumer is indifferent to the actual meaning of these concepts. In the context of market production, the concept of entertainment, as a human activity, is combined with media industry, forming a complex of Media and Entertainment Industry (MEI), which is constantly growing and evolving phenomenon.

The prospects of IME as a branch of national production with high innovative, investment and consumer potential, "catch the eye" not only of rhe owners of global companies, but also one of governments.

Peculiar features of the industry are due to the high degree of integration between concepts of "media" and "entertainment", which both act like complementary as well as sructural elements of each other. A critical 
aspect that distinguishes modern understanding of MEI as an industry from its historical predecessors is the criterion of commercial orientation.

The article examines the peculiarities of the formation and interpretation of the internal structure of the media and entertainment industry (MEI), the peculiarities of MEI services as a product sold on a specialized market are analyzed, the preconditions of MEI clustering within the national market are studied, in particular, objective and immanent factors are singled out. Also, the example of the clustered national MEI market is analyzed, thus the weaknesses and strengths of this form of organization for this industry are highlighted.

The article substantiates the expediency of cluster organization of IME services production within the national market, and also offers a comprehensive interpretation of the definition of "media and entertainment industry", taking into account the peculiarities of consumer behavior and organization of the production process in this market.

Key words: media, entertainment, media and entertainment industry, world market of services, production cluster.

Постановка проблеми у загальному вигляді та іï зв'язок 3 важливими науковими і практичними завданнями. Фактичне визначення індустрії медіа та ентертейменту (Media and Entertainment Industry) будується описово, за принципом теоретичного узагальнення існуючих ринкових фактів. Відсутність наукового підходу до визначення меж даної галузі виробництва спричиняє неможливість іiї комплексної оцінки та адекватної прогностики в межах національного та світового ринків на вищому, аніж прогнозування мод та рівнів продажів, рівні.

Аналіз останніх досліджень, у яких започатковано вирішення проблеми. Медіа індустрія та ентертейменту характеризується мінливістю зв'язків та швидкими темпами трансформації іiі структурних компонентів, що перетворює іiі на джерело глобальних змін і $є$ передумовою їх одночасно. Переважна більшість досліджень окресленої проблематики здійснювалася іноземними науковцями, серед яких Alfred Hermida, Josep Valor, Nic Newman, Wayne Woodward та ін. Особливу увагу дослідники, в тому числі і в Україні, зосередили на рекламно комунікативному ринку, глобальному ринку B2B, особливостях DIGITAL-маркетингу. Аналіз даних досліджень дає підстави стверджувати про недостатність уваги науковців дослідженням трансформації медіа індустрії та ентертейменту, їх впливу на конкурентоспроможність країн.

Наведемо приклади визначень внутрішньогалузевої структури IME, що пропонуються спеціалізованими платформами з ринкової аналітики:

a) Традиційне ТБ та відео, кінематограф, стримінгові сервіси/платне медіа (ОТТvideo, Over-The-Top-video), відео-ігри та онлайн спорт, реклама в інтернеті [1];

б) ТБ, кінематограф, відео-ігри, паблішинг (блоги, онлайн преса), музика [2];

в) Кінематограф, ТБ, радіо та паблішинг [3].

Також варто відмітити те, що відсутні чіткі формулювання структури окресленої сфери. Існує також нечіткість у виділенні музики, радіо та реклами як самостійних продуктивних елементів, а також де-факто розбіжність у структурі та характері послуг та процесі їх виробництва між традиційним ТБ та ОТТ-ТБ.

Цілі статті: дослідити внутрішньогалузеву структури індустрії медіа та ентертейменту, проаналізувати особливості послуг, що виробляються IME, як ринкового продукту, визначити передумови кластеризації IME в межах національного ринку та проаналізувати економічну доцільність даного виду організації IME з позицій національного виробництва та його перспектив на світовому ринку, а також запропонувати комплексне трактування дефініції «індустрії медіа та ентертейменту», зважаючи на особливості поведінки споживача та організації виробничого процесу в умовах даного ринку.

Виклад основного матеріалу дослідження 3 обгрунтуванням отриманих наукових результатів. Зважаючи на високий рівень прибутковості індустрії медіа та ентертейменту, як продуктивної галузі світового господарства, невизначеність в науковому розумінні її внутрішньої структури, передумов та перспектив розвитку, може 
носити фатальний характер для виробничого потенціалу національних ринків IME в умовах світової конкуренції.

Існуючі «білі плями» можна пояснити специфічністю самого процесу виробництва в галузі та відносною молодості IME (Індустрії Медіа та Ентертейменту). 3 позиції логічного аналізу ці факти пояснюються високим ступенем інтегрованості понять «медіа» та «ентертейменту», які виступають водночас взаємними доповненнями та елементами одне одного. Сегмент медіа традиційно охоплює засоби або платформи для подачі продукту споживачеві (преса, радіо, ТБ), а сегмент ентертейменту корелює 3 мистецькою творчою діяльністю та визначає змістове наповнення продукту. Проте, розділяти медіа та ентертеймент, як елементи IME, виключно за ознакою інформативності/розважальності не коректно та неможливо. Це пояснюється фактом існування їхнього суміжного продукту, який де-факто замінив собою елемент «медіа» в сучасній структурі IME, витіснивши діяльність новинних агентств за межі індустрії.

Суміжний продукт медіа та ентертейменту - специфічний різновид продукту, що виробляється та споживається на ринку IME, та поєднує в собі інформативну та розважальну складові обох сегментів.

Прикладом подібного продукту на різних етапах історичного розвитку медіа та ентертейменту є «злободенний продукт», тобто такий вид продукту, який:

- розважає та містить важливу інформацію про стан сучасного суспільнополітичного та культурного укладу суспільства;

— містить важливу інформацію про стан сучасного суспільно-політичного та культурного укладу суспільства та розважає;

- розвага та інформування відбувається водночас.

Його прикладами в сучасних умовах є пісні, що стосуються конкретних суспільнополітичних кризових явищ, реалізм в кіно та реалізм в масовому продукті (реаліті шоу).

В ринковому розумінні, індустрія медіа та ентертейменту - комплексна індустрія, що здійснює комерційне виробництво та реалізацію розважальних послуг, використовуючи апарат медіа, як засіб комунікації зі споживачем, та включає в себе продуктивні підгалузі індустрій кінематографу, 2-d та 3-d анімації, серіали, відео-ігор, ринок лейблової музики, розважальне ТБ, розважальне радіо, розважальний паблішинг.

Попит на послуги IME формується на двох засадах: психологія маси (продукти поп-культури) та психологія індивіда (вузькопрофільні продукти). Основною потребою, що визначає попит на послуги IME, $є$ психологічна потреба людини в емоціях та враженнях.

На думку Р. Стеббінса, ентертеймент вирізняється тим, що повністю відволікає увагу людини від усього іншого, створюючи ефект «занурення» [4]. Тому, постійно зростаюча активність споживання послуг IME (а отже і постійне зростання ринку IME) пояснюється психологічною специфікою іiі споживача - фактом відчудження людини від власного життя та його середовища, глобальна тенденція до якого почала зароджуватись у ХХ ст. [5, с. 37-41].

Для типового виробника послуг IME характерне існування двох видів продуктивних центрів: безпосередній правовласник та безпосередній виробник послуг. Безпосередній правовласник - це юридична структура, яка займається вербуванням, наймом і менеджментом публічних «зірок» та творчих генераторів (авторів сценаріїв, композиторів, музикантів-аранжувальників, тощо), а також допоміжного персоналу. В залежності від підгалузі IME безпосереднім правовласником може бути музичний лейбл, кіностудія чи загалом компанія з надання послуг ентертейменту (entertainment company). Безпосередній виробник послуг — талановита харизматична особа, яка привертає увагу та здатна змусити споживачів любити себе та свій продукт завдяки зовнішнім, особистісним та/або професійним даним. Ним може бути як безпосередньо «зірка»або 
«товарне обличчя», так і поєднання «зірки», як амбасадора або представника контенту, та власне автора оригінального творчого продукту, який є непублічним, або не надто публічним.

Оскільки задоволення споживчої потреби в емоціях та враженнях відбувається завдяки контакту (безпосередньому чи уречевленому) споживача саме з «зіркою» або автором продукту, а не 3 правовласником, забезпечення та обслуговування цього контакту - його основне завдання. Воно не обмежується лише організацією середовища для фізичної зустрічі чи випуском уречевленого продукту (диску, кіноплівки, сценарію, тощо), а включає в себе широкий спектр дій з підготовки, виробництва та реалізації уречевленого продукту, обслуговування та організації продуктивної діяльності зірки і постійної підтримки зв'язку між зіркою та споживачем завдяки фізичним зустрічам.

Фактично таку кількість завдань непросто ефективно здійснювати потужностями окремо взятої фірми-виробника, особливо якщо вона є невеликою. Тому, оптимальною формою організації підприємницької діяльності у сфері ентертейменту в межах національного ринку є виробничий кластер.

Враховуючи те, що попит на продукцію індустрії ентертейменту будується на задоволенні психологічних потреб споживача, кластерна організація виробництва послуг IME дозволяє максимально комплексно охопити його («огорнути» надаваними послугами), отримавши при цьому максимальний одномоментний дохід.

Цьому передують такі передумови:

- психологічні особливості споживачів послуг IME напряму пов'язані з їхнім менталітетом та культурними особливостями, що є географічно-детермінованими;

- споживачі 3 подібним способом життя, економічними та соціальними характеристиками, психологічними вподобаннями, формують окремі регіони за географічним та економічним принципами;

- споживачі послуг IME постійно контактують одне 3 одним, формуючи потенційний попит на продукт, який задовольняє їх самих, у контактних осіб, коло яких обмежується географічно;

- один продукт індустрії IME може задовольнити споживача різними способами.

Перші три передумови $є$ об'єктивно обумовленими, натомість четверта - $€$ суб'єктивною іманентною характеристикою індустрії. Саме вона є основною причиною ефективності комплексної кластеризації IME, адже всебічно реалізуючи творчий потенціал продукту, виробник послуги може максимізувати не просто сукупний дохід (екстенсивний показник), а дохід, отримуваний з одного споживача (інтенсивний показник).

Досягнути подібної максимізації можна лише за умови високого рівня розвитку каналів внутршіньокластерової взаємодії між його продуктивним центрами та обслуговуючими галузями. При чому, отримувані вигоди від подібної співпраці $\epsilon$ двосторонніми: безпосередні виробник послуги та правовласник отримують додатковий прибуток від реалізації тимчасового унікального продукту та залучення нових споживачів, натомість обслуговуюча галузь гарантовано отримує прибуток від комерційної авантюри завдяки постійним фанатам «зірки» та створює додатковий інтерес до себе з боку споживачів та партнерів.

За умови інтенсивного використання даних зв'язків можна максимально швидко, якісно та комплексно наситити внутрішній ринок ентертейменту і водночас виділити галузь спеціалізації з абсолютними перевагами на світовому ринку, яка буде найбільш цікава, незвична, національна та вдала за якісними характеристиками водночас. При чому, прибуток в одній з підгалузей IME створить додатковий прибуток і в інших, за ефектом синергії.

Відповідно, маючи досвід успішного захоплення внутрішнього ринку та економічну «подушку безпеки», яку він надає, національний виробник послуг IME 
зможе здійснювати експансію на міжнародному ринку, спираючись на стратегічне планування, а не «голий шанс» чи «умови, які зараз найкраще мені допоможуть».

Прикладом комплексної кластеризації IME в межах національного ринку можна вважати ринок послуг IME Японії. 3 позиції формальності, відповідно до національного класифікатора індустрій Японії, увесь спектр послуг IME в поєднанні з індустрією преси формують Індустрії Інформації та Комунікацій (категорія G в класифікаторі) [6]. Ïї особливістю $\epsilon$ цікавий підхід до виділення підгалузей в сфері інформації, що базується на засобі створення інформації, який уточнюється способом його безпосередньої подачі споживачу. Ще одним важливим фактом, наявним в цьому класифікаторі, є виділення установ, що займаються адмініструванням та надають допоміжні послуги кожній індустрії, в окрему класифікаційну одиницю.

Подібний підхід свідчить про високий рівень спеціалізації юридичних осіб на певному виді діяльності, при чому всі можливі ресурси та резерви виробник направляє на безпосередню продуктивну діяльність, яка здійснюється завдяки різного роду взаємодіям з аналогічними виробниками, материнськими та дочірніми структурами, підприємствами суміжних галузей. 3 вищевказаного можна прийти до висновку, що на ринках Японії активно налагоджуються, підтримуються та обслуговуються інфраструктурні «містки взаємодії» між окремими галузями та підприємствами, що складають основу для кластерної кооперації в межах галузей виробництва загалом.

Особливістю ринку IME Японії, на противагу до європейсько-американського регіону, $є$ те, що живі заходи для нього є не способом отримування прибутку, а засобом просування основної послуги, традиційно уречевленої у формі диска або медійних послуг ТБ з поступовим зростанням використання стримінгових платформ. Це пояснюється комерційним потенціалом власного ресурсу IME. Як наслідок галузі IME обслуговують маркетингові потреби одна одної та тісно взаємодіють із пресою.

Постійне зближення та операційна взаємодія між підгалузями IME відбувається поступово, на основі «природних» ринкових передумов.

3 позиції ринкової практики, символічна для Японії індустрія аніме, як похідна від виробництва манги (оригінальних японських коміксів), є найзручнішою відправною точкою, для обгрунтування переваг кластеризації IME та особливостей іiї здійснення.

Одним із іiі умовних символів $\epsilon$ професія сейю (сейю (声優 ) - скорочення від кое-но-хаі-юу (俳優の声) — «актор/актриса озвучування»). До професійних обов'язків сейю входять: озвучування радіо- та аудіодрам, ігор, реклами, перекладів іноземного продукту (фільмів, серіалів, анімації, телевізійних програм) та власної анімації. Починаючи з 2000-них, через «місток» цієї професії, відбулось поступове зближення галузі виробництва аніме з музичною індустрією, що в подальшому призвело до зближення комплексу виробництва аніме та музичної індустрії та їхніх суміжних, похідних та первинних галузей, з виробництвом ігор, програмного забезпечення, телевізійного та радіоконтенту. При чому, позитивний синергетичний ефект отримують усі сторони подібного роду взаємодії.

Проілюструємо це на наступних прикладах. Однією з найбільш відомих серед фанатів аніме, японських музики та ігор, $є$ франшиза UtaPri, яка у 2020 році відсвяткувала 10-літній ювілей (повна назва - Uta no Prince-sama, латинізація оригінальної назви プリンスさまっ々うたの (《Пісня пана-принца»)). Її первинним продуктом є візуальна новела в жанрі отоме (отоме, від яп. 乙女 «дівчина» — різновид розважального контенту, орієнтованого на жіночу аудиторію) для портативної PlayStation (PSP, PlayStation Portable), виробником якої є корпорація Sony. Перша гра із основної серії була випущена 24.06.2010p. Структуру франшизи представлено у таблиці 1. 


\begin{tabular}{|c|c|c|}
\hline Елемент франшизи & Галузь & Безпосередній власник та бенефеціари \\
\hline 1. Основна гра (в т.ч.) & Виробництво ігор & $\begin{array}{l}\text { Broccoli Co., Ltd } \rightarrow \text { GungНо Online Entertainment, Inc. } \rightarrow \\
\text { колишній власник та власник 35,03 \% копманії SoftBank } \\
\text { Group }\end{array}$ \\
\hline озвучка & Послуги сейю & Агенції з менеджменту сейю \\
\hline \multicolumn{3}{|c|}{ основна пісенна тема, в т.ч. } \\
\hline Власні пісні Міяно Мамору & $\begin{array}{c}\text { Музичне } \\
\text { виробництво }\end{array}$ & King Records Co., Ltd $\rightarrow$ Kodansha Ltd \\
\hline $\begin{array}{l}\text { Оригінальні пісні Elements Garden y } \\
\text { виконанні офіційного складу сейю }\end{array}$ & $\begin{array}{l}\text { Послуги сейю, } \\
\text { музичне } \\
\text { виробництво }\end{array}$ & $\begin{array}{l}\text { Агенції з менеджменту сейю; Elements Garden } \rightarrow \text { Aria } \\
\text { Entertainment Co., Ltd }\end{array}$ \\
\hline 2. Аніме (4 сезони) (в т.ч.) & $\begin{array}{l}\text { Виробництво } \\
\text { анімації, } \\
\text { телеіндустрія, } \\
\text { стримінгові } \\
\text { послуги }\end{array}$ & $\begin{array}{l}\text { A-1 Pictures Inc. } \rightarrow \text { Aniplex } \rightarrow \text { Sony Music Entertainment } \\
\text { Jараn } \rightarrow \text { Sony Corporation; } \\
\text { постачальники послуг ТБ; } \\
\text { Niconico } \rightarrow \text { DWANGO Co., Ltd. } \rightarrow \text { Kadokawa } \\
\text { Corporation }\end{array}$ \\
\hline озвучка & Послуги сейю & Агенції з менеджменту сейю \\
\hline закордонний реліз & $\begin{array}{l}\text { Послуги компанії з } \\
\text { легалізації } \\
\text { іноземних релізів } \\
\text { японських } \\
\text { продуктів }\end{array}$ & $\begin{array}{l}\text { Sentai Filmworks } \rightarrow \text { Sentai Holdings, LLC } \rightarrow \text { перебуває під } \\
\text { опікою та сприянням державної програми METI «Cool } \\
\text { Japan» }\end{array}$ \\
\hline \multicolumn{3}{|c|}{ оригінальні саундтреки, в т.ч. } \\
\hline Власні пісні Міяно Мамору & $\begin{array}{c}\text { Музичне } \\
\text { виробництво }\end{array}$ & King Records Co., Ltd $\rightarrow$ Kodansha Ltd; \\
\hline $\begin{array}{l}\text { Оригінальні пісні Elements Garden y } \\
\text { виконанні офіційного складу сейю }\end{array}$ & $\begin{array}{l}\text { Послуги сейю, } \\
\text { музичне } \\
\text { виробництво }\end{array}$ & $\begin{array}{l}\text { Агенції з менеджменту сейю } \\
\text { King Records Co., Ltd } \rightarrow \text { Kodansha Ltd }\end{array}$ \\
\hline $\begin{array}{l}\text { 3. Театральні постановки за } \\
\text { мотивами пісень }\end{array}$ & $\begin{array}{l}\text { Театральне } \\
\text { мистецтво }\end{array}$ & Касові збори постановників та прибутки театрів \\
\hline 4. Анімаційний фільм & $\begin{array}{l}\text { Виробництво } \\
\text { анімації, } \\
\text { кіноіндустрія }\end{array}$ & $\begin{array}{l}\text { A-1 Pictures Inc. } \rightarrow \text { Aniplex } \rightarrow \text { Sony Music Entertainment } \\
\text { Japan } \rightarrow \text { Sony Corporation; } \\
\text { касові збори в обсязі } 1.72 \text { млрд єн [7] }\end{array}$ \\
\hline 5. Манга & Виробництво манги & $\begin{array}{l}\text { журнал шьоджо манги Sylph } \rightarrow \text { публікується завдяки } \\
\text { ASCII Media Works } \rightarrow \text { Kadokawa Future Publishing } \rightarrow \\
\text { Kadokawa Corporation }\end{array}$ \\
\hline 6. Мобільний додаток (гра) & $\begin{array}{l}\text { Виробництво ігор, } \\
\text { виробництво } \\
\text { мобільних ігор }\end{array}$ & $\begin{array}{l}\text { Broccoli Co., Ltd } \rightarrow \text { GungНо Online Entertainment, Inc. } \rightarrow \\
\text { колишній власник та власник } 35,03 \text { \% копманії SoftBank } \\
\text { Group; } \\
\text { KLab Inc. }\end{array}$ \\
\hline 7. Лайви (в т.ч.) & Промоушн & $\begin{array}{l}\text { Broccoli Co., Ltd } \rightarrow \text { GungHo Online Entertainment, Inc. } \rightarrow \\
\text { колишній власник та власник 35,03 \% копманії SoftBank } \\
\text { Group }\end{array}$ \\
\hline послуги сейю & Послуги сейю & Агенції з менеджменту сейю \\
\hline $\begin{array}{c}\text { тематичний мерчандайз (включно } 3 \\
\text { blu-ray тa dvd) }\end{array}$ & Промоушн & $\begin{array}{l}\text { Broccoli Co., Ltd } \rightarrow \text { GungHo Online Entertainment, Inc. } \rightarrow \\
\text { колишній власник та власник } 35,03 \text { \% копманії SoftBank } \\
\text { Group; } \\
\text { спеціалізовані аніме рітейлори }\end{array}$ \\
\hline 8. Офіційний мерчандайз & Промоушн & $\begin{array}{l}\text { Broccoli Co., Ltd } \rightarrow \text { GungНо Online Entertainment, Inc. } \rightarrow \\
\text { колишній власник та власник 35,03 \% копманії SoftBank } \\
\text { Group; } \\
\text { спеціалізовані аніме рітейлори }\end{array}$ \\
\hline
\end{tabular}

\section{Джерело: авторська розробка}

3 таблиці 1 видно, що франшиза, яка виникла в межах індустрії з виробництва ігор, постійно створює зайнятість та прибуток як іншим підгалузями IME, так і суміжним для IME галузям (театральне мистецтво, рітейл). Проте, іï вплив на прибутки в межах комплексу IME не обмежуються простим арифметичним сумуванням. Франшиза, будучи 
популярною серед фанатів аніме, отоме-ігор та ігор для мобільних телефонів, додатково пожвавлює інтерес та попит на творчо-професійну діяльність всього акторського складу сейю, який значною мірою інтегрований у підгалузі виробництва музики, розважального ТБ та суміжну галузь радіо, а також працює за посередництва різних агенцій та співпрацює з різними лейблами.

Другим прикладом в контексті IME Японії, зокрема сегментів анімації та музики, $\epsilon$ відоме для споживачів як всередині країни, так і закордоном, ім'я сейю студії Ken Production, соліста і автора лірики групи Granrodeo Таніями Кішо (谷山 紀章, Taniyama Kishō). Його дебют як сейю відбувся у 1994 р., формування Granrodeo, як музичного дуету із соліста Таніями Кішо та композитора Ідзуки Масаакі (飯塚 昌明, Izuka Masaaki) відбулось у 2005 р., завдяки спільній роботі над аніме проєктами.

Фактично, безпосередня професійна діяльність Таніями Кішо як сейю створює:

$>$ індивідуальний дохід;

$>$ дохід агенції, що займається організацією та плануванням його робочого графіку;

> комплексу IME, зокрема підгалузям виробництва анімації, виробництва ігор, ТБ та ОТТ-ТБ, музичного виробництва, кіновиробництва;

обслуговуючим галузям, зокрема підприємствам 3 рітейлу, фото-студіям, засобам масової інформації, посередникам в організації живих заходів.

Його діяльність як виконавця в підгалузі виробництва музики в свою чергу створює:

— індивідуальний дохід;

— дохід агенції, що займається організацією та плануванням його/їі робочого графіку;

— музичному лейблу та студії звукозапису;

— комплексу IME, зокрема підгалузям виробництва анімації, виробництва ігор, ТБ та ОТТ-ТБ;

- обслуговуючим галузям, зокрема підприємствам з рітейлу, фото-студіям, засобам масової інформації, посередникам в організації живих заходів.

Тобто, фактично професійна діяльність одної людини, створює продукт та дохід в кожній 3 підгалузей в межах IME та суміжних галузях, при чому у випадку прибутковості взаємодії відбувається посилення взаємозв'язків між підгалузями (за принципом прецеденту).

Різнобічне підсилення «зірки» Таніями Кішо створює додаткову вартість продуктам його діяльності у всіх напрямах спеціалізації та постійно розширює попит на них, що залучає кошти його фанатів до відповідних галузей (перетікання споживчого попиту між галузями).

Тобто, за умов кластеризації національного ринку IME в Японії, фанат аніме, який де-факто витрачає кошти на тематичний мерчандайз, продукти та відвідування заходів, зацікавившись особою сейю, стане витрачати додаткові кошти на продукти, мерчандайз та заходи, пов'язані з його/ії іншими видами діяльності: чим ширша ця діяльність, тим більше галузей отримують додатковий дохід та потенційний споживчий попит. В умовах некластеризованої національної системи IME подібний ефект $є$ обмеженим, оскільки мережа зв'язків між підгалузями є вужчою.

Основними відмінностями між кластеризованим національним ринком IME Японії та співпрацею між галузями IME в світі є наступні:

a) продукт однієї галузі не створює дохід іншим у вигляді перетікання споживчого попиту між галузями; 
б) навіть якщо в кіно, мультфільми чи серіали запрошують зірок 3 інших підгалузей IME, то це за суттю піар-акції, а не створення галузевого продукту, який використовується для просування «зірки».

Саме потенціал продуктів IME як засобів просування товару, поступово зближує підгалузі IME на національних ринках та може вважатись вихідним пунктом кластеризації в межах національного ринку.

В розрізі МЕВ комплекс IME Японії розглядається, аналізується та підтримується державою в рамках стратегії «Cool Japan», яка передбачає досягнення японськими виробниками послуг IME наступних цілей: створення "японського буму” (позитивного та привабливого становища японських продуктів в очах закордонних споживачів) $\rightarrow$ продажі на іноземних риках (забезпечення інфраструктури) $\rightarrow$ продажі в Японії (зацікавити та «змусити» споживача відвідати Японію та надати перевагу купівлі продукту всередині країни, на противагу до купівлі закордоном) [8, с. 9].

Основною перешкодою до реалізації ринкового потенціалу IME Японії в умовах світового ринку є мовний бар'єр, який чинить найменший вплив на музичну індустрію, проте значно впливає на інші підгалузі на приблизно однаковому рівні.

Так внаслідок комплексної кластеризації, музичний ринок Японії є другим у світі за величиною створюваного доходу після музичного ринку США (таблиця 2).

ТОП-5 найбільших музичних ринків за річним обсягом продажів

\begin{tabular}{|c|c|c|c|c|c|}
\hline & 2015 & 2016 & 2017 & 2018 & 2019 \\
\hline 1 & США & США & США & США & США \\
\hline 2 & Японія & Японія & Японія & Японія & Японія \\
\hline 3 & Велика Британія & Велика Британія & Німеччина & Велика Британія & Велика Британія \\
\hline 4 & Німеччина & Німеччина & Велика Британія & Німеччина & Німеччина \\
\hline 5 & Франція & Франція & Франція & Франція & Франція \\
\hline
\end{tabular}

Джерело: складено за $[9 ; 10 ; 11 ; 12 ; 13]$.

Зважаючи на це, та існуючу тенденцію до використання стримінгових платформ, як основного середовища для організації комерційної діяльності IME в умовах світового ринку (частка стримінгу в структурі загальних продажів світового музичного ринку складає: 12,8 \% у 2014 р., 19,3 \% у 2015 p., 29,1 \% у 2016 p., 38,2 \% у 2017 p., $\quad$ 49,2 \% у 2018 р. та 56,4 \% у 2019 р. відповідно [9]), для виробників галузі доцільною є орієнтація саме на них в процесі реалізації продукту закордонним споживачам.

У випадку Японії, політика «продажів в Японії» та особливості національного ринку IME країни (суворі заходи проти плагіату та реалізація матеріальних носіїв, як основна стаття галузевого прибутку), як не парадоксально, заважають фактичному здійсненню подібного роду орієнтації. Проте постійно відбуваються позитивні зрушення. Японські виробники послуг IME починають пристосовувати власні стримінгові платформи, до можливості їхнього використання споживачами з-за кордону (до прикладу, платформа AbemaTV [14]), а також поступово реалізують власний контент на міжнародних стримінгових платформах, зокрема Netflix та Spotify.

B сфері рітейлу такі гіганти як CD Japan (продаж аудіо записів) та Animate (аніме продукція та мерч) пропонують іноземних покупцям отримати бажаний товар, скориставшись послугами міжнародних поштових служб. Проте, значним недоліком $є$ оформлення покупки японською мовою, хоча сайти і пропонують англомовну покрокову мапу здійснення замовлення.

Висновки. Таким чином, на нашу думку, кластерна форма організації виробництва послуг IME в межах національного ринку дозволяє максимально швидко та 
комплексно побудувати конкурентноспроможну галузь для виходу на світовий ринок. Її позитивний вплив на національний ринок представлені у таблиці 3.

Позитивні ефекти від кластеризації IME в межах національного ринку

\begin{tabular}{|c|c|}
\hline Показник & Характер та наслідки впливу \\
\hline $\begin{array}{c}\text { Рівень зайнятості в галузі IME та } \\
\text { загалом }\end{array}$ & $\begin{array}{l}\text { Інтенсивна взаємодія між галузями IME дозволяє створити } \\
\text { максимальну трудову зайнятість представників творчих } \\
\text { професій, які часто є не надто прибутковими на рівні типового } \\
\text { митця, а також усього персоналу, який займається } \\
\text { адмініструванням та обслуговуванням його діяльності. }\end{array}$ \\
\hline $\begin{array}{c}\text { Середній рівень доходу працівника } \\
\text { IME }\end{array}$ & $\begin{array}{l}\text { Оскільки діяльність працівника відбувається не лише в межах } \\
\text { його власної підгалузі, але і в інших, він отримує додатковий } \\
\text { зовнішній дохід. }\end{array}$ \\
\hline Рівень прибутковості галузі IME & $\begin{array}{l}\text { Інтенсивна взаємодія між галузями IME дозволяє максимально } \\
\text { використати споживчий потенціал одного продукту, або одного } \\
\text { виробника послуг IME; }\end{array}$ \\
\hline $\begin{array}{c}\text { Потенціал продукції галузі IME на } \\
\text { міжнародному ринку }\end{array}$ & $\begin{array}{l}\text { Конкуренція в межах кластера IME дозволяє швидко } \\
\text { викристалізувати підгалузь абсолютних переваг на } \\
\text { міжнародному ринку та максимально забезпечити її вихід в } \\
\text { світове середовище ресурсами внутрішнього ринку. }\end{array}$ \\
\hline
\end{tabular}

Джерело: авторська розробка. таблиці 4.

Слабкі сторони кластеризації національного комплексу IME представлені в

Таблиця 4

Слабкі сторони кластеризації IME в межах національного ринку

\begin{tabular}{|c|l|}
\hline Показник & \multicolumn{1}{|c|}{ Характер та наслідки впливу } \\
\hline Рівень зайнятості в галузі IME та загалом & $\begin{array}{l}\text { Створюєтья постійна потреба в професійних кадрах, яка за } \\
\text { неспиятливих умов на ринку праці може призвести до } \\
\text { кадрового голодування та збитків в усіх підгалузях загалом. }\end{array}$ \\
\hline Рівень прибутковості галузі IME & $\begin{array}{l}\text { Падіння рівня прибутковості однієї з підгалузей та втрата } \\
\text { нею споживчого інтересу гостро зачепить усю систему IMЕ. }\end{array}$ \\
\hline Потенціал продукції галузі IME на & $\begin{array}{l}\text { Комфортне положення виробників послуг IME в межах } \\
\text { маціонального ринку може призвести до небажання } \\
\text { вихотити на світовий ринок та поступової стагнації } \\
\text { компексу. } \\
\text { Комплексність надаваних послуг в межах національного } \\
\text { ринку вимагає створення комплексної інфраструктури для } \\
\text { аналогічного «огортання» ними і закордонного споживача. }\end{array}$ \\
\hline
\end{tabular}

Джерело: авторська розробка.

Проте не існує такого способу виробництва, який не передбачав би ризики. Отже, кластеризація IME володіє потенціалом, який здатний створити «ринкове диво» в межах галузі за умови комплексності, відкритості та постійного характеру здійснення «кроків на зустріч» представниками усіх продуктивних підгалузей виробництва.

\section{Список бібліографічного опису}

1.US Edition: Entertainment \& Media Outlook 2020-2024. PWC US. URL: https://www.pwc.com/us/en/industries/tmt/library/global-entertainment-media-outlook.html (accessed: 13.12.2020).

2. The Global Media and Entertainment (M\&E) industry outlook 2020. Televisory. URL: https://www.televisory.com/blogs///blogs/theglobal-media-and-entertainment-m-e-industry-outlook-2020 (accessed: 13.12.2020). 
3.Media And Entertainment Industry Overview. Vault. URL: https://www.vault.com/industries-professions/industries/mediaand-entertainment (accessed: 13.12.20).

4.Robert A. Stebbins The Sociology of Entertainment. URL: https://www.researchgate. net/publication/259503018_The_Sociology_of_Entertainment. (accessed: 13.12.2020).

5.Е. Фромм. Мати або бути? Книжковий Клуб «Клуб Сімейного Дозвілля. Переклад Г. В. Яновська. 2020 р. 304c.

6.JAPAN STANDARD INDUSTRY CLASSIFICATION VER 13 OCTOBER 2013. URL: https://www.eujapan.eu/sites/default/files/imce/government_procurement/8-a-i-12 jsic list.docx (accessed: 13.12.2020).

7.Rafael Antonio Pineda. Uta no Prince-sama Film Earns 1.72 Billion Yen After 17 Weeks. Anime News Network. URL: https://www.animenewsnetwork.com/news/2019-10-09/uta-no-prince-sama-film-earns-1.72-billion-yen-after-17-

weeks/.152041 (accessed: 13.12.2020)

8.Content Industry Current Status and Direction of Future Development METI. Ministry of Economy, Trade and Industry of Japan. URL: https://www.meti.go.jp/english/policy/mono_info_service/content_industry/pdf/ 20160329001.pdf (accessed: 13.12.2020).

9.Global Music Report. The Industry in 2019. IFPI URL: https://www.ifpi.org/wpcontent/uploads/2020/07/Global_Music_Report-the_Industry_in_2019-en.pdf (accessed: 13.12.2020).

10. Global Music Report. The Industry in 2018. IFPI URL: https://www.cudisco.org/pdf/GLOBAL-MUSIC\%20REPORT2019.pdf 2018 (accessed: 13.12.2020).

11. Statistics Trends. The Recording Undustry of Jaoan in 2017. RIAJ. URL: https://web.archive.org/web/20180618052745/https://www.riaj.or.jp/riaj/open/open-record!file?fid=1638 2017 (accessed: 13.12.2020).

12. Statistics Trends. The Recording Undustry of Jaoan in 2016 . RIAJ. URL: https://web.archive.org/web/20170808064127/http://www.riaj.or.jp/riaj/open/open-record!file?fid=1474 2016 (accessed: 13.12.2020).

13. Statistics Trends. The Recording Undustry of Jaoan in $2015 . \quad$ RIAJ. URL: https://web.archive.org/web/20170724054057/http://www.riaj.or.jp/riaj/open/open-record!file?fid=13812015 (accessed: 13.12.2020). 14. Abema TV. Official site. URL: https://abema.tv/ (accessed: 13.12.2020).

Edition: Entertainment \& Media Outlook 2020-2024. PWC US. URL: https://www.pwc.com/us/en/industries/tmt/library/global-entertainment-media-outlook.html (accessed: 13.12.2020).

2. The Global Media and Entertainment (M\&E) industry outlook 2020. Televisory. URL: https://www.televisory.com/blogs/-/blogs/theglobal-media-and-entertainment-m-e-industry-outlook-2020 (accessed: 13.12.2020).

3. Media And Entertainment Industry Overview. Vault. URL: https://www.vault.com/industries-professions/industries/mediaand-entertainment (accessed: 13.12.2020).

4. Robert A. Stebbins The Sociology of Entertainment. URL : https://www.researchgate. net/publication/259503018_The_Sociology_of_Entertainment. (accessed: 13.12.2020).

5. E. Fromm. Maty abo buty? Knyzhkovy Klub «Klub Simeinoho Dozvil'ia». Pereklad H. V. Yanivs'ka. 2020. 304p. [in Ukrainian].

6. JAPAN STANDARD INDUSTRY CLASSIFICATION VER 13 OCTOBER 2013. URL: https://www.eujapan.eu/sites/default/files/imce/government_procurement/8-a-i-12_jsic_list.docx (accessed: 13.12.2020).

7. Rafael Antonio Pineda. Uta no Prince-sama Film Earns 1.72 Billion Yen After 17 Weeks. Anime News Network. URL: https://www.animenewsnetwork.com/news/2019-10-09/uta-no-prince-sama-film-earns-1.72-billion-yen-after-17weeks/.152041 (accessed: 13.12.2020)

8. Content Industry Current Status and Direction of Future Development METI. Ministry of Economy, Trade and Industry of Japan. URL: https://www.meti.go.jp/english/policy/mono_info_service/content_industry/pdf/20160329001.pdf (accessed: 13.12.2020).

9. Global Music Report. The Industry in 2019. IFPI URL: https://www.ifpi.org/wpcontent/uploads/2020/07/Global Music Report-the Industry in_2019-en.pdf (accessed: 13.12.2020).

10. Global Music Report. The Industry in 2018. IFPI URL: https://www.cudisco.org/pdf/GLOBAL-MUSIC\%20REPORT2019.pdf 2018 (accessed: 13.12.2020).

11. Statistics Trends. The Recording Undustry of Jaoan in 2017. RIAJ. URL: https://web.archive.org/web/20180618052745/https://www.riaj.or.jp/riaj/open/open-record!file?fid=1638 2017 (accessed: 13.12.2020).

12. Statistics Trends. The Recording Undustry of Jaoan in 2016. RIAJ. URL: https://web.archive.org/web/20170808064127/http://www.riaj.or.jp/riaj/open/open-record!file?fid=1474 2016 (accessed: 13.12.2020).

13. Statistics Trends. The Recording Undustry of Jaoan in 2015. RIAJ. URL: https://web.archive.org/web/20170724054057/http://www.riaj.or.jp/riaj/open/open-record!file?fid=13812015 (accessed: 13.12.2020).

14. Abema TV. Official site. URL: https://abema.tv/ (accessed: 13.12.2020).

Дата подання публікації 15.12 .2020 р. 